International Relations in China and Europe:

the Case for Interregional Dialogue in a Hegemonic Discipline

Kristensen, Peter Marcus

Published in:

Pacific Review

DOI:

10.1080/09512748.2014.948568

Publication date:

2015

Citation for published version (APA):

Kristensen, P. M. (2015). International Relations in China and Europe: the Case for Interregional Dialogue in a Hegemonic Discipline. Pacific Review, 28(2), 161-187. [1]. https://doi.org/10.1080/09512748.2014.948568 


\title{
International Relations in China and Europe: the Case for Interregional Dialogue in a Hegemonic Discipline
}

\author{
Peter Marcus Kristensen \\ University of Copenhagen
}

\begin{abstract}
The International Relations discipline (IR) is known as an 'American Social Science' dominated by scholars and theories from the US core. This paper compares IR in two non-core settings, China and continental Europe. It shows that there is a growing institutional and intellectual integration into the global Anglophone, mostly American, IR in both Europe and China. Both Chinese and European IR communities have tried to establish top Anglophone journals like the European Journal of International Relations and the Chinese Journal of International Politics that can spearhead their integration into mainstream Anglophone IR and carve out a space for regional thinking. Yet, an analysis of their publications finds that while both the Chinese and the European journal functions as outlets for Chinese and European scholars, respectively, they also tend to publish a high number of Americans and rely heavily on American sources. Meanwhile, there is very little integration and exchange between Chinese and European IR. The paper presents a number of arguments why Chinese and European IR would benefit from a dialogue, especially regarding 'schools' of IR at the margins of an 'American social science'. The paper uses questionnaire survey data and an analysis of articles published in the European Journal of International Relations and the Chinese Journal of International Politics to support these arguments.
\end{abstract}




\section{The International Relations of a Hegemonic Discipline}

The International Relations discipline (IR) is widely known to have its origins in the AngloAmerican world and to be dominated by Anglo-American researchers. Whether myth or reality, the history conventionally told is that IR was conceived in bleak interwar Wales but was born and raised in baby boom America after the Second World War. Its intellectual parents might have had thick German accents and horrifying experiences from the European continent, but during its early teens IR left this milieu behind and grew up to become an "American social science", a real science like its older brother economics (Hoffmann 1977). Non-US relatives who scrutinized their family tree confirmed that IR had a certain "birthmark"-its American bias-(Krippendorff 1987:34) and that it lived in a "British-American intellectual condominium" (Holsti 1985:103).

Recent years have seen a growing interest in IR scholarship outside the Anglo-American world. The long forgotten European cousins with their exotic and 'reflectivist' profile have been emphasized as a source for a more diverse, and less inbred, family get-together (Wæver 1998; Jørgensen 2000; Friedrichs 2004; Jørgensen and Knudsen 2006a). Some optimistically predicted that the "Europeanization of IR" would eventually break American hegemony, at least qualitatively if Americans remained quantitatively superior (Groom and Mandaville 2001:163). Although continental Europeans are perhaps still seen as visitors passing by for the annual gathering held in a major American city and occasionally sending a postcard, European IR scholars have actively tried to escape the claustrophobic British-American condo and instead build a "house with many mansions" (Friedrichs 2004). Therefore, European IR is no longer the "best kept secret" 03/10/2017 14.10 but rather in a semi-peripheral position in the global discipline (Aydinli and Mathews 2000; 
Friedrichs and Wæver 2009). At least in relative terms, compared to non-Western relatives who hardly even have a place in the "House of IR", and if so, at best as "servants" and "wards" (Agathangelou and Ling 2004:27). Self-reflective scholars have shifted their attention from American dominance over European semi-peripheries to American-Western dominance over the non-Western periphery (Aydinli and Mathews 2000; Tickner 2003; Tickner and Wæver 2009; Acharya and Buzan 2010). Yet, a recent overview of the global family showed that IR largely remained an American social science, with the possible exception of China (Tickner and Wæver 2009:336). Chinese IR scholars stood out because they have long been debating whether and how to develop "IR with Chinese characteristics" (Liang 1997; Chan 1998; Callahan 2001; Song 2001) or, more recently, a Chinese theory or "school" of IR (Qin 2007, 2011; Wang 2007, 2009; Ren 2008; Yan 2011).

Many of these debates on alternative perspectives on IR have taken place within China and scholars in the Anglo-American core have paid very little attention (much the same can be said about continental European approaches to IR). But both European and Chinese IR have been reorienting theoretical debates towards the mainstream discipline, a process which is in part supported by the establishment of English-language IR journals both on the European continent and in mainland China. It is interesting to compare Chinese and European IR because both have been seen as holding the promise for a more diverse discipline. Moreover, it is somewhat surprising that the two have never engaged, except through the hub-and-spokes system organized around the American core. There is certainly room for more Sino-European intellectual dialogue and a more systemic comparison of their similarities and differences and this paper is an initial attempt to fill out that gap. The focus will also be on their relationship to the American core, more specifically the role American scholars and American sources play in the Chinese and European journals examined and the broader communication patterns in the two regions. 
The paper proceeds in three sections. First, the paper outlines the broader institutional framework for careers and publishing in Chinese and European IR. This section argues that there is a growing institutional and intellectual integration into the global Anglophone, and often American, journal market in both Europe and China. It draws upon survey data among IR scholars in Europe and China. Second, the paper analyzes articles published in two key Anglophone journals in China and Europe. The analysis of the European and Chinese journal finds that although they are outlets for European and Chinese scholars, respectively, American IR is omnipresent in both. Both the Chinese and the European journal tend to publish a high number of Americans and rely heavily on American sources. The paper finds little integration and exchange between Chinese and European IR, however. Third, the paper argues that European and Chinese might benefit from greater dialogue, especially regarding 'schools' of IR at the margins of an 'American social science'.

\section{European and Chinese IR in a Hegemonic Discipline}

There is a variety of ways to study the social workings of academic disciplines. This paper relies on both questionnaire survey data, interviews and journal data. It primary approach to the question of European and Chinese IR within the 'American social science', however, is to study academic journals. The communication patterns of academic journals are interesting because journal data provide a direct indicator of the discipline (Wæver 1998:697). Journals review, sanction and disseminate 'IR knowledge' (Goldmann 1995; Wæver 1998; Breuning, Bredehoft, and Walton 2005). As regimes of truth that draw the lines between what counts as accredited knowledge and what does not, they provide a useful place to examine the exercise of disciplinary power. Journals are important institutions not only because they validate and disseminate knowledge but also because their accreditation affects material payoffs and in some cases even careers. Therefore, this 
section will first outline the institutional setting and journal markets in Europe and China before moving on the analysis of the form and content of the two journals studied. It asks what role journals and academic publishing play in the making of IR careers in China and Europe and whether it is possible to talk about 'Chinese' and 'European' journal markets. In short, it looks at the political economy of publishing in Europe and China.

\section{Careers and Publishing in European IR}

There are still few studies of 'European IR' in toto, but rather a number of single or comparative case studies of national IR communities in Europe (the main comparative works are Friedrichs 2004; Jørgensen and Knudsen 2006a and the following will rely mainly on these). The reason is probably that there are many IR communities in Europe with distinct national, regional, linguistic, cultural characteristics, and - perhaps even more importantly in the context of the political economy of 'European IR' - that they are embedded in diverse university systems with their respective science policies and academic career patterns. These differences notwithstanding, the overall trend is that academic publications in leading (often Anglo-American) peer-reviewed journals are becoming more important as a mechanism for the control of both symbolic and material benefits. The prestige of certain Anglo-American journals is also confirmed by (West) European IR scholars themselves in the recent TRIP survey where respondents from Ireland, UK, France, Denmark, Finland, Norway and Sweden ranked American journals International Organization, International Security and International Studies Quarterly and British/European journals Review of International Studies and European Journal of International Relations as the most influential on how IR scholars think. When asked to rank research outputs that can advance your academic career, single-authored, peer-reviewed articles and single-authored books in a university press come out far ahead of other 
output in all European countries (Maliniak, Peterson, and Tierney 2012:52). While this might reflect an overall trend in European IR, the prestige of these journals and the institutional pressure towards publishing in them is not evenly distributed throughout Europe. Publishing in them can be very difficult and may not be necessary for making a career in some European countries.

At the most integrated end of the continuum one finds the United Kingdom, which is part of the "Anglo-American core" (Holsti 1985:103). The reasons are many, ranging from linguistic advantages and a long disciplinary history through more institutional factors such as the biggest and most organized IR community in Europe that controls several leading journals and book presses and not least a research bureaucracy that strongly incentivizes publications in such journals (Jørgensen and Knudsen 2006a:5, 2006b). The European continent, in contrast, is in a more peripheral or semiperipheral position vis-à-vis the American core-a position where 'international' Anglophone journals are mainly consumed while regional and domestic publications continue to play a large role for careers (Aydinli and Mathews 2000; Jørgensen 2000; Friedrichs and Wæver 2009).

The Nordic countries, and perhaps the Dutch and German-speaking countries, are characterized by an intermediate position — a strategy called "multi-level research cooperation" by one observer-where they have worked in-between the national, regional, European and globalAmerican IR market (Friedrichs 2004:66; Friedrichs and Wæver 2009:262). An important part of this strategy was the establishment of 'regional international' journals published in English—such as Cooperation and Conflict (the main English-language journal of the Nordic Association), Security Dialogue, Journal of Peace Research and Scandinavian Political Studies-and their subsequent 'internationalization', which elevated some of them to top-tier international journals that attract international submissions and readers while they remain controlled by Nordic scholars and outlets for Nordic scholars. Nordic scholars have thus kept a national academic market while also getting "access to big editorial markets and to the inner circles of discursive power" (Friedrichs 
2004:66). The Nordic inclination towards English-language publications is also a product of “incentives for internationalization - read increased mobility and communication within Englishlanguage areas" (Jørgensen and Knudsen 2006a:5). Nordic IR is one of the regions where science policies and performance-based evaluation criteria have led to a growing demand for publications in leading international journals and even high citation scores (Friedrichs and Wæver 2009:270).

Towards the other end of the 'core-periphery' spectrum, Central and Eastern Europe has been described as "weakly penetrated" by trends from the "core" (Drulák, Karlas, and Königová 2009:251-3). There are trends towards 'internationalization' as evidenced the establishment of the Journal of International Relations and Development (the English-language journal of the Central and East European International Studies Association) but few Central and Eastern European researchers are able to publish in international journals, even JIRD, and domestic publications remain the main output for making a career in this region (Drulák et al. 2009:251-3). Southern European countries are also in a more marginal or isolated position. Italy (and Spain) assumes a position of "resigned marginality" where trends from the mainstream and its journals are imported but very little is exported to the mainstream journals (Friedrichs and Wæver 2009:262). Domestic journals in the native language play a more important role, but perhaps most important for advancing one's career is the relationship to the local professor or faculty (Lucarelli and Menotti 2006:62). Spain is perhaps even more "invisible" in the discipline and has few, if any, journals dedicated to IR (Segura 2006:109). Finally, a country like France tends to not even import trends from the mainstream English-language journals but is characterized by "academic self-reliance" on domestic publications (Lucarelli and Menotti 2006:62).

Overall, European IR is a "house with many mansions" (Friedrichs 2004) where national communities pursue different strategies vis-à-vis the mainstream American discipline and its journals. But the "house" is becoming more integrated and the establishment of European journals 
of high international standards and published in English is part of this process (Friedrichs and Wæver 2009:279). The establishment of European Journal of International Relations (EJIR) embodies the trend of constructing and strengthening the 'regional international' journal market as a strategy of coping with American hegemony. EJIR was established in 1995 and has become the most prestigious European IR journal, at least measured on common indicators of prestige: It has an impact factor of 1.352 and thus ranks $11^{\text {th }}$ in the IR category in the Web of Science. It is the highest ranked European journal in the global TRIP survey where it ranks $7^{\text {th }}$ among all IR journals, and enjoys a particularly high reputation among European based scholars (Maliniak et al. 2012:51-53). It is the journal of Standing Group of International Relations of the European Consortium of Political Research and is thus institutionally anchored in Europe. Whether it represents 'European IR' is another question. As the results below show, it publishes a growing number of US-based authors (who might, of course, do 'European-style IR'). EJIR is an interesting case because it was established to spearhead the entrance of European IR on the global IR market. It never had an empirical area focus on Europe or the EU but simply provided a peer-reviewed English-language outlet that was edited and controlled by Europeans. It might have been sympathetic to 'Europeanstyle IR' but attracts articles on non-European topics written and read by both continental European and Anglo-Saxon scholars.

\section{Careers and Publishing in Chinese IR}

There are some tangible differences between the Chinese and European IR. The Chinese IR market is more homogenous and unitary due to linguistic and institutional similarities. Although it remains stratified and has coastal-inland and perhaps Beijing-Shanghai divides, Chinese IR is one, fairly large, market where scholars primarily publish in China-based journals in Mandarin and attempt to 
climb a career ladder in the same university system. But Chinese IR also shares some similarities with European IR. Both increasingly reward publications in widely disseminated English-language journals and have thus established their own English-language journals of high international standards.

Chinese academia has also experienced a series of reforms in the past decades where publications, especially in academic journals, have become increasingly important means of making a career. The 'iron rice bowl' system of egalitarian pay and life-long job security has been abolished and so (gradually) have the politicized hiring and promotion practices that culminated under the Cultural Revolution. Instead, "Western-style" remuneration and hiring schemes have increasingly been adopted (Yan 2010:104-106). Like in Western academia, research publications, primarily in journals, constitute the key pillar of the performance-based remuneration and promotion system adopted by most universities (Chen 2003:124; Wei 2010:271). International publications are highly valued by the university system and "pressure has been applied to social scientists to publish in international journals" (Huang 2010:75). The incentives for making it into the top global journals are high; the reward for an article in a journal indexed in the Web of Science may be equivalent to $10 \%$ of annual salary (Chen 2003:113-114). Chinese IR also reflects this changing incentive structure (Huang 2007:195). Table 1, displaying the results from a survey conducted among Chinese IR scholars in the summer of 2010, shows that respondents rank "publishing in academic journals" as the most important criteria for promotion to professor, much more important than international recognition, teaching, government projects, networks or media appearances: ${ }^{\mathrm{i}}$

\section{[insert table 1]}

When asked more specifically to list which academic journals have the greatest influence on the way IR scholars think, Chinese scholars rank American journals like International Organization, 
International Security and Foreign Affairs as the top three-like their European colleagues. Yet, there is an important difference between journals that are perceived as influential and the journals where Chinese careers are actually made. Chinese IR scholars rarely publish in 'international' or Web of Science categorized IR journals [author self-citation], especially considering that China has one of the world's largest IR communities (Zhang 2002:101; Qin 2007:316). This is not only because publishing internationally is difficult, but also because the national journal market remains the most important for Chinese careers. The reliance on national journal markets is a characteristic of the social sciences in China (Zhou, Su, and Leydesdorff 2010:1361). The creation of two Chinese equivalents to SSCI attests to the size of national social science markets and their importance in terms of career and university rankings (Liu and Liu 2005:219, 221). The number of Chinese IR journals has also been growing rapidly (Wang 2002:9). As table 2 shows, a majority of Chinese IR scholars find it most important to publish in Chinese journals (53\%):

[insert table 2]

It is also worth noting that a substantial percentage finds it most important for them to publish in American journals (32\%) while very few find it important to publish in European journals (4\%). The orientation towards 'international' audiences - almost exclusively American audiences at the moment - is also reflected in the theoretical debates in the Chinese discipline. While the 1980s and 1990s saw calls for 'IR with Chinese characteristics' that were about nationalizing rather than Westernizing IR by giving it a Chinese flavor and was primarily oriented towards national audiences, the recent debates about a Chinese school of IR have a more international orientationas part of the global family of IR theories. But as the dissemination of Chinese research in 
American journals has proven difficult, an alternative strategy is to internationalize Chinese journals along the lines of American journals. The gradual reform, perhaps mainstreaming and Americanization, of the Chinese journal market was supported by a generational shift in the editorial boards: “the editorial boards of China's leading IR journals, including Contemporary International Studies and World Economy and Politics, tend to be dominated by those who are trained in the U.S. or who are familiar with the US-based scholarship of IR" (Zhang 2003:102). In consequence, the trend goes towards Americanization and scienticization, of journals. Chinese Journal of International Politics (CJIP) is the journal that comes closest to an embodiment of the strategy of internationalizing and scientizing Chinese journals along the lines of top American journals. CJIP is very explicit about this goal, but it should also be noted that Wang Yizhou, the longtime editor of the leading journal World Economy and Politics, has also been characterized as paradigmatic of scientism (Wang 2009:115).

CJIP is chosen here because it as an English-language China-based aims to be a bridgehead for Chinese and China-related IR within the global-American discipline. CJIP was established in 2006 with support from the MacArthur Foundation and has become the leading Anglophone IR journal in China, despite being a relatively new journal. It is the only China-based IR journal in the Web of Science database (excluding Chinese Journal of International Law). It was only recently included in the database and is not yet included in the Journal Citation Report that measures impact factor, so its relative Impact Factor ranking remains to be seen. As an English-language academic IR journal based and edited in China, CJIP is predominantly a 'Chinese' journal. It is not published by a national or regional association like EJIR, but has its institutional home and editorial base at Tsinghua University and is edited by two Chinese scholars. As shown below, its authors are primarily based in China and it has a distinct empirical focus on China. 
As leading English-language journals in the Chinese and European IR community, respectively, EJIR and CJIP are thus interesting for a comparison. Both are at the margins of an American-dominated discipline and were born out of a position of resistance, speaking from and representing an alternative geographical standpoint to (Anglo-)American IR (one can only wonder why else would it be necessary to have 'Chinese' and 'European' in the titles? American-based IR journal rarely have 'American' in their name, just think of the top journals in the TRIP survey International Organization, International Studies Quarterly, International Security, World Politics and American Political Science Review as the exception that proves the rule). CJIP and EJIR, on the other hand, were explicitly established and baptized as marginal journals speaking from and representing somewhere. Especially in the case of CJIP, the periphery strategy indicates that it is not a self-proclaimed universal journal, but an international Chinese journal that functions as outlet for Chinese ideas. EJIR has hardly retained a marginal position but is developing into a mainstream journal whose 'European-ness' is found less in its empirical area focus than its openness towards reflectivist and interpretivist IR. For the purpose of the present argument, the analysis of EJIR and CJIP will look firstly at the geographical base of its authors, secondly at the number, age and network among cited sources and thirdly at their content and profile.

\section{Geographical Affiliations}

Since CJIP is only published since 2006, the analysis looks at research articles in both journals published in the period 2006-2012. This yields 78 articles from CJIP and 156 articles in EJIR. ${ }^{\text {ii }}$ With respect to the geographical profile of the authors published in each journal, one might expect that CJIP and EJIR, as Chinese and European journals, would tend to publish Chinese and European authors. So it is noteworthy that both journals tend to publish not only 'local' but also a higher 
number of American authors. Meanwhile, there are relatively few Chinese authors in EJIR and few Europeans in CJIP as table 3 also shows:

[insert table 3]

Around half the authors in CJIP are based in China (51\%). Apart from the national dominance of China-based scholars in CJIP, there is also a clear Beijing-centrism as more than one third of all articles are written by Beijing-based scholars (37\%) while Shanghai comes in as a far second (7\%). The US is also well represented (26\%) and English-speaking countries like England, Canada, Singapore and Australia account for almost all other articles (17\%). In EJIR, on the other hand, Americans actually constitute the largest group published (29\%), and the Anglo-Saxon IR communities in the US, UK, Australia and Canada are the four most published and together account for two thirds of the articles in EJIR (65\%). It is somewhat surprising that Continental Europe only accounts for approximately the same as the US or UK each (28\%).

To visualize this 'geography of knowledge', the maps below show the city-level distribution of authors using a GPS geocoder to produce city coordinates of research articles and Google Maps to visualize them (Leydesdorff and Persson 2010). It also maps geographical co-authorships between cities, i.e. when an article has two or more authors whose geographical affiliation is not in the same city (visualized here by red lines). Cities are sized according to number of authors and marked red circles for cities with coauthorship link and orange for cities with a scientific output but no coauthorship links. Figure 1 shows the global network of CJIP articles:

[insert figure 1] 
Note the high concentration around Beijing and the high number of contributions scattered around a number of North American cities. The city-level concentration is much lower for EJIR. Instead, it is worth noting that EJIR articles are primarily published by authors based in Western Europe and Northeast America. There is little cross-publication and co-authorship between China and Europe, though. This supports the argument of Chinese and European insularity plus an American connection, hub-and-spokes system of the IR discipline. Figure 2 shows the authorship network in EJIR 2006-2012:

[insert figure 2]

In sum, CJIP has a higher concentration of its authorship with authors primarily based in China, Beijing (and even Tsinghua) compared to EJIR's more dispersed profile. Both CJIP and EJIR primarily publish 'local' and American scholars., yet CJIP has the most 'local' profile. It might thus be more similar to Nordic strategy of establishing high-quality, English-language journals that worked as key outlets for Nordic scholars in the early years of the Nordic discipline. Journals that remain based and edited in the Nordic region, but have gradually been 'internationalized' and now attract a broader readership and authorship (Friedrichs 2004:66).

\section{Citation Patterns}

This section studies citation patterns in the two journals. It looks first as CJIP and EJIR as citing journals, i.e. their knowledge base, and then as cited journals, i.e. their 'impact'. The focus is specifically on the knowledge base cited in the discourse of each journal, the number, age and geographical base of cited sources. In the citation analysis below, top sources cited in the two 
journals are compared. The bibliographies of all 78 CJIP articles and 156 EJIR articles are imported from the Web of Science and homogenized manually by checking if any sources occur under two or more different titles. Table 5 shows the 20 most cited sources in each journal:

[insert table 5]

The most cited sources in both CJIP and EJIR are journals. They cite many of the same journals but the ranking of journals varies. International Organization is by far the most cited journal in EJIR, while International Security is the most cited in CJIP. The citation pattern of CJIP generally indicates a higher focus on security matters-International Security, Security Studies, Journal of Conflict Resolution and Foreign Affairs all rank higher than in the citation pattern of EJIR. When looking at geography, both journals tend to cite American and 'local' (Chinese or European) journals. The EJIR list ranks EJIR and Review of International Studies much higher than CJIP does and several other European journals like Millennium, Journal of Peace Research, International Affairs and International Relations are among the most cited in EJIR while none of them are in the top 20 in CJIP. CJIP, on the other hand, cites academic IR journals based in China (Shijie Jingji Yu Zhe [World Economics and Politics], Daodan Yu Hangtian Yunzai Jishu [Missiles and Space Vehicles] and Chinese Journal of International Politics) as well as journals with an area focus on Asia (Asian Survey and International Relations of the Asia-Pacific). None of these are among the most cited sources in EJIR. Both journals are thus somewhat parochial in citing 'local' sources, which may be natural given their area focus. When knowledge is imported from journals based elsewhere, scholars in China and Europe look to the 'American social science', which enjoys a privileged position in both journals. The seven most cited sources in CJIP are American journals, while six of the ten most cited sources in EJIR are American journals. It is remarkable how many 
citations and thus knowledge is exchanged (imported) across the Atlantic and Pacific and how little is exchanged across the Eurasian continent.

A similar pattern of European and Chinese insularity plus an American connection can be found when looking at the journals' impact, i.e. their cited pattern. CJIP's citation impact has primarily been within other China- or Asia-related journals: it receives most citations from CJIP itself, International Relations of the Asia-Pacific, Journal of Contemporary China, Pacific Focus, Asian Security Studies, China - An International Journal, China Journal, Chinese Journal of International Law, Foreign Policy Analysis, Issues \& Studies, Third World Quarterly. Its articles have been cited almost equally by scholars based in the US and Canada (29\%), Europe (26\%), China (21\%) and the Asia-Pacific including Australia and New Zealand (22\%). There is thus further evidence that CJIP is very China-focused as it has had an impact mainly in China and Asia-Pacific scholarship (albeit on scholars based in a relative wide range of countries). EJIR articles have primarily had an impact on European IR journals. Most citations come from Security Dialogue, EJIR itself, Review of International Studies, Millennium, International Political Sociology, International Relations, International Studies Review, Journal of International Relations and Development, International Politics and Cambridge Review of International Affairs. Although most of these citing journals are arguably more generic IR journals than those citing CJIP, it is noteworthy that most are based in Europe. When looking at the location of authors that cite EJIR, it is also evident that the majority is based in Europe (59.3\%). A significant share of citing authors are based in the US and Canada (27.4\%) some in Australia, New Zealand and Israel (9.3\%) and few in the rest of the world (4\%).

Both journals have thus primarily had an impact on their own region's journals and scholars and a low impact on American IR. This is paradoxical considering how often American journals are cited in CJIP and EJIR. Knowledge continues to flow from the American core to the European and 
Chinese periphery, not the other direction. It is worth looking briefly at the content of the published most cited articles in each journal to see whether and how they have published articles with a specifically ‘European' and 'Chinese' (or perhaps American) profile.

\section{Content and Profile}

The following section analyzes the content and profile of the two journals through a reading of the most cited articles in each journal and the editorial material available on each journal's profile. Although editorial statements and journal websites usually tell less about the content and profile of a journal than it does about academic buzzwords - methodological pluralism, theoretical diversity, interdisciplinarity and the like-there are actually some differences between EJIR and CJIP, especially in terms of empirical focus and methodological profile.

The empirical focus of CJIP is apparent in the editorial statement that "Most of its articles are either related to China or have implication for Chinese foreign policy." (CJIP 2012). More specifically, China's rise and Chinese ideas are two of its three editorial pillars (the third being theoretical work). As an editorial stated, the journal invites submission on "the theoretical, policy, and the analytical implications of China's rise [and] Chinese ideas, historical and contemporary, about international relations and foreign policy." (CJIP 2010:2). There is a large number of policyrelated articles on contemporary Chinese foreign policy or China's relationship to the US, EU and India. When reading the most cited CJIP articles, it becomes clear that there is a focus not just on China, but the rise of China and the debate over the "Peaceful Rise" of China. This debate contains articles written by both Chinese and Anglo-American scholars and it is worth noting that the most cited Anglo-American scholars see the prospects for Peaceful Rise as "difficult” (Buzan 2010:35), if not "downright depressing" (Mearsheimer 2010:396) and warn against "exceedingly unpleasant" 
consequences (Tammen and Kugler 2006:55). Meanwhile, the most cited papers written by Chinese scholars tend to be more optimistic and positive about peaceful rise-ranging from constructivists that see it as "possible and realizable" if its identity continues to be status quo rather than revisionist (Qin 2010:152) to realists arguing that a rising China can shape its environment in ways favorable to its continued rise (Yan 2006:33) and eventually "bring about a world order more peaceful and secure than that today" (Yan 2008:159). A number of these and other articles touch upon the question of China's "soft power", its ability to attract and co-opt (Yan 2006, 2008; Mingjiang 2008; Hunter 2009; Hall 2010) and question whether China will automatically be a revisionist rising power and whether power transition are always unpeaceful (Yongping 2006; Huiyun 2009). Note that the Peaceful Rise debate tends to be framed in opposition to mainstream American realist theories about rising powers (e.g. power transition theory).

Peaceful Rise has been a core puzzle driving the debate over a so-called "Chinese School" of IR theory (Qin 2007, see also 2011:245; Acharya and Buzan 2007:290). The aim to contribute, or intervene into, the debate over a Chinese School is explicit in several CJIP articles (Buzan 2010; Cunningham-Cross and Callahan 2011; He 2011; Paltiel 2011; Zhang 2011; Nianshen 2012). The debate has taken place in two related subfields in CJIP - one more historical and empirical, the other more philosophical and theoretical. The first strand of research focuses on Chinese Imperial history, particularly the tributary system (Zhou 2011 is the most cited; but see also Xiaomin and Chunfeng 2007; Zhou 2007; Zhang 2009; Nianshen 2012; Yuan-kang 2012; Yongjin and Buzan 2012; Womack 2012). While these articles are clearly more historical, they are usually framed around the contemporary puzzle of peaceful rise in their introduction and conclusion. As one author argues, "the greater contemporary attention to the tributary system and more generally to 'Tianxia' is rooted in China's peaceful rise." The same can be said about the second, and more philosophical, strand of research that introduces ancient Chinese philosophical classics such as Mozi, Mencius and 
Xunzi into IR (Yan 2008 is the most cited; but see also Paltiel 2010; Zhongbo and Ning 2008; Li 2009) and the numerous several articles responding to editor Yan Xuetong's book Ancient Chinese Thought, Modern Chinese Power.

CJIP has indeed been spearheading a more theoretical and philosophical movement towards theorizing ancient Chinese thoughts and experience in IR, but its turn to IR theorizing is only part of a broader trend in Chinese IR. While most IR journals in China have tended to focus on policy research (Zhang 2002, 107), the leading IR journals have published more theoretical studies in recent years. As Qin Yaqing shows in a quantitative study, one third of the articles published from 1991 to 2000 in the most prestigious Chinese journal, World Economics and Politics, focused on theory (Qin 2007, 2009, 319). 713 theory-related articles were published between 2001 and 2007, averaging 101.9 articles annually_a 200\% increase compared to the period from 1991 to 2000 (Qin $2009,191)$. Another study shows that $11 \%$ of journal articles in IR carried by leading journals in 1996-2001 were devoted to 'theory-building', only topped by 'area studies' (49\%) and 'great power relations/international strategy' (17\%) (Wang 2002, 9). Chinese journals are becoming more receptive to 'theory' articles and CJIP is no exception. Meanwhile, most CJIP articles also have a focus on policy relevance for China's peaceful rise today and this specific policy dimension is characteristic of CJIP, especially when compared to EJIR.

EJIR does not have an equally strong empirical focus on Europe, the EU, its foreign policy or bilateral relations nor are EJIR publications driven by an overall European puzzle equivalent to China's "Peaceful Rise". But when looking at the most cited articles in EJIR in the period covered, they do have a 'European flavor' in that they tend to take a more reflectivist, sociological or constructivist approach: several of the most cited articles are on risk, security and the war on terror. While they do not always self-identify as 'securitization studies' or 'critical security studies', several articles engage and criticize the 'Welsh School' of Critical Security Studies and the 
'Copenhagen School' of securitization (Aradau and Van Munster 2007; Stritzel 2007; De Goede 2008; Mcdonald 2008; Vuori 2008). Another strand of research identifies with 'constructivism', not necessarily mainstream 'middle-ground' constructivism, but a multitude of works ranging from social psychology, emotions and affect through Gramscian hegemony theory to studies of coercive rhetoric (Flockhart 2006; Ross 2006; Ish-Shalom 2006; Krebs and Jackson 2007; Lipson 2007). The most cited EJIR articles differ in numerous and important ways and the point is not to homogenize them under the 'European constructivism' or 'reflectivism' straitjacket—such a label would do as little justice to their nuances as would 'Chinese School' to CJIP articles. Nevertheless, even articles that do not self-identify as social constructivist, reflectivist or deconstructivist tend to be informed by (European) social theory (e.g. ontological security inspired by the work of Anthony Giddens (Mitzen 2006); or a governmentality reading drawing upon the work of Foucault(ians) (Bartelson 2006)). In the comparison to CJIP, it is notable that more rational choice is the exception rather than the rule in EJIR.

While EJIR claims that it "represents no particular school or approach, nor is it restricted to any particular methodology" (EJIR 2012), CJIP explicitly adheres to the scientific method. CJIP takes scientism and American IR as the model (Wang 2009:117) and encourages "modern methodology" such as quantitative and statistical methods (CJIP 2012). It is perhaps not so surprising to find game theoretic frameworks such as Prisoner's dilemmas and Chicken games applied to conventional subjects like conflict mediation (Haixia 2007), negotiations (Gang 2006) and deterrence (Ganghua and Yongxian 2007). But CJIP's claim to scientism is more surprising considering that it has been a key outlet for articles exploring traditional Chinese thought on international relations and debates over a Chinese school of IR. There is nevertheless a tendency to hybridize the traditionally humanistic study of ancient history and philosophy with 'modern' social science methodologies. To take some examples, CJIP has published a game-theoretic analysis of the 
Tributary System (Zhou 2011) the Opium War (Zhou 2010), a game-theoretical reading of the ancient Chinese philosopher Mozi (Li 2009) and a reorganization of the philosopher Xun Zi's thoughts into independent and dependent variables and power formula according to "modern scientific standards" (Yan 2008:140). Not all CJIP articles subscribe to the 'scientific methodology' and there is probably an overweight of descriptive and historical case studies, but CJIP and the socalled "Tsinghua School” around the journal are known as China's center for 'scientific IR' (He 2011:10; Yan 2011:255; Zhang 2011:2). In this regard, it is once again important to stress again that CJIP is published in English and aims at an 'international' (read: American) audience. Due to the difficulties of publishing in US-based leading journals, it has become a very clear goal of the leading Chinese journals to be recognized internationally. Promoting American-style scientism is a paradoxical way of countering US hegemony, but perhaps effective in providing an outlet for Chinese scholarship which is considered 'high quality' by the American discipline. One can only wonder if the Chinese strategy has been overly focused on the US, however, and that they might would benefit from dialogue with European IR, for example on how to theorize traditional thought in IR, classical-humanistic approaches and methodologies and not least about regional-national 'schools' at the margins of the 'American social science'.

\section{The Case for Dialogue}

Both CJIP and EJIR have established themselves as leading regional journals that attract submissions primarily from both local and US scholars. As this paper has shown, there has been remarkably little cross-fertilization between Europe and Asia in terms of publishing in and citing each other's journals, however. European and Chinese IR could benefit from more dialogue across the Eurasian landmass. One reason is that they are, in some important ways, in a similar position 
vis-à-vis the American mainstream. Neither Chinese nor European theorists have been very successful in gaining much attention in the American mainstream where it is still widely believed that only Americans can do "big thinking" (Walt 2011). Perhaps the European 'schools' like the English School-that for some reason do not qualify as theories proper, but as geographical schools - have been the closest. The English School has actually become increasingly popular in Chinese IR in recent years. Paradoxically, and very telling for the global communication pattern in IR, the English School entered China from the United States (Zhang 2003).

The English School gained popularity as Chinese scholars became aware of the dominance of American approaches to IR (Ren 2008:297) and saw the English School as a more historically nuanced and less deterministic approach to China's rise. Several scholars have noted how English School traditionalism, as opposed to American scientism, has been embraced by Chinese IR scholars (Zhang 2003; Qin 2009:191; Wang 2009:109) and that one attraction of the English School is that its classical, historical and philosophical approach is more compatible with the Chinese intellectual tradition than scientific and quantitative approaches (Zhang 2003:99-100). Even CJIP, allegedly the stronghold of scientism in China, has been open to contributions from and debate over the English School (Zhang 2009; Buzan 2010; Qin 2010; Zhang and Buzan 2010; Yongjin and Buzan 2012). And vice versa, Review of International Studies perhaps the closest to a home for the English School is by far the European, and even Western, journal that has been most receptive to Chinese scholarship [author self-citation].

In interviews with Chinese IR scholars, several saw the turn to the English School as a reaction against simplistic American theories that predict Sino-US conflict. The English School provided a "much more sophisticated" and "much more modest" approach more aligned with traditional Chinese intellectual culture, as one interviewee put it: "So I think to some extent the perspective of the English School is much closer to the Chinese traditional approach to knowledge. 
Because you might know that it is the tradition of Chinese philosophy to emphasize the balance of analysis so it is not a good thing to reach an oversimplified conclusion from the analysis. We have to see the different aspects of reality, the good or bad." (Interview professor Peking University, March 2010). In a similar move, another interviewee characterized the Copenhagen School as "quite different" and "quite comprehensive" compared to the "American perspectives". As he further argued, "This is why I try to introduce the Western, the Copenhagen school's ideas to the Chinese audience[...] ]otherwise most Chinese people do not differentiate American and European." (Interview associate professor Fudan University, March 2010).

As the above analysis of CJIP shows, 'scientific' IR also has followers in China and the classical and historical approach characteristic of the English School is certainly not embraced by all. But European IR 'schools' remain popular, if not only for their more comprehensive and nuanced content, then also for their form as geographical 'schools' in opposition to dominant American theories; the fact that the English school is seen as an "IR theory with English characteristics" that distinguishes itself from American theories (Zhang 2003, 95-96) makes it a model for a 'Chinese school' of IR or an IR theory with 'Chinese characteristics'. The Chinese opposition to dominant American theories led to the attraction to 'national international' theory and the English School is seen as the role model here. The growing attention to different geographical epistemologies was catalyzed in part by a reading of the hegemonic "American social science" that was more critical of the "American" than the "social science" part (Callahan 2004:306). This again explains why social scientism remains relatively popular - at least in CJIP and the Tsinghua School — and is adopted by some in the search for a Chinese IR theory.

Moreover, the mere presence of an English School raises a question posed by several Chinese IR scholars: if there can be geographical schools of IR in England—and even Copenhagen, Wales and Paris—why not a Chinese school? (Ren 2008:297; Wang 2009:110; on the inspiration from the 
English and Copenhagen schools, see also Paltiel 2011:376; Zhang 2011:3). The school strategy can thus be seen as an attempt to carve out an international niche for a certain geographical standpoint. 'School' signifies a non-competitor to the major theories that define the discipline: "the main theories that are seen as constituting the core debates at the centre of the discipline (i.e. leading circles in the US) are not referred to as "schools"” (Wæver 2004:11). A school is allowed for an independent existence, but is not fully recognized as an equal contender. And the prospects for attention, not to speak of recognition, in the mainstream American discipline seem dire. One of the few Americans who has waved the flag in the Chinese School debate does not have "confidence in the generalizability of the results when Chinese international relations scholars state that the core theoretical problem of the Chinese School should be 'China's peaceful rise", but argues that it misses "the point of what is normally called theory", that is, "value-neutral terms that carry across time and space for comparative purposes" (Snyder 2008:4-5).

But the geographical school project is more than a strategy for recognition, it also writes itself into the larger (thus far mainly European) project of resistance to universal knowledge claims that speak from no-where and thus every-where at the same time. It negates the very across all "time and space" definition of theory in the American critique above. Rather, it can be seen as a localizing strategy and a call for taking the local conditions of knowledge production seriously, both in the hegemonic American-Western 'core' and the subordinated 'periphery'. A heightened awareness to the partial, local and situated origins of knowledge might paradoxically make knowledge claims more objective (Haraway 1988). In this endeavor, too, European and Chinese IR would have much to gain from an inter-regional dialogue. Thus far there has been little Sino-European engagement, however. There are indications that both European and Chinese IR have been either engaged in internal debates or gazing at the US. A first step towards a post-hegemonic discipline would be to 
move beyond the hub-and-spokes model of intellectual communication where all interaction between different regions goes through the American center.

\section{References}

Acharya, Amitav, and Barry Buzan, Eds. (2010) Non-Western International Relations Theory. Abingdon: Routledge.

Acharya, Amitav, and Barry Buzan. (2007) Why Is There No non-Western International Relations Theory? An Introduction. International Relations of the Asia-Pacific 7: 287-312.

Agathangelou, Anna, and L.H.M. Ling. (2004) The House of IR: From Family Power Politics to the Poisies of Worldism. International Studies Review 6: 21-49.

Aradau, Claudia, and Rens Van Munster. (2007) Governing terrorism through risk: Taking precautions, (un)knowing the future. European Journal of International Relations 13: 89115.

Aydinli, Ersel, and Julie Mathews. (2000) Are the Core and Periphery Irreconcilable? The Curious World of Publishing in Contemporary International Relations. International Studies Perspectives 1: 289-303.

Bartelson, Jens. (2006) Making Sense of Global Civil Society. European Journal of International Relations 12: 371-395.

Breuning, Marijke, Joseph Bredehoft, and Eugene Walton. (2005) Promise and Performance: An Evaluation of Journals in International Relations. International Studies Perspectives 6: 447461.

Buzan, Barry. (2010) China in International Society: Is "Peaceful Rise" Possible? Chinese Journal of International Politics 3: 5-36.

Callahan, William. (2001) China and the Globalisation of IR Theory: Discussion of "Building International Relations Theory with Chinese Characteristics". Journal of Contemporary China 10: 75-88.

Callahan, William. (2004) Nationalising International Theory: Race, Class and the English School. Global Society 18: 305-323.

Chan, Gerald. (1998) Toward an International Relations Theory with Chinese Characteristics? Issues \& Studies 6.

Chen, Xiangming. (2003) The Academic Profession in China. In Philip Altbach (ed) The Decline of the Guru: The Academic Profession in the Third World. Palgrave Macmillan. 
CJIP. (2010) Editor-in-Chief Statement on the Transition to Quarterly Publication. The Chinese Journal of International Politics 3: 1-2.

CJIP. (2012) Oxford Journals | Chinese Journal of International Politics | About the Journal. Available at: http://www.oxfordjournals.org/cjip/about.html.

Cunningham-Cross, Linsay, and William Callahan. (2011) Ancient Chinese Power, Modern Chinese Thought. Chinese Journal of International Politics 4: 349-374.

Drulák, Petr, Jan Karlas, and Lucie Königová. (2009) Central and Eastern Europe: Between Continuity and Change. In Arlene Tickner and Ole Wæver (eds) International Relations Scholarship Around the World. London and New York: Routledge.

EJIR. (2012) European Journal of International Relations. SAGE. Available at: http://www.sagepub.com/journals/Journal200942?prodId=Journal200942\&ct_p=aimsAndSc ope. (Accessed October 24, 2012).

Flockhart, Trine. (2006) "Complex socialization": A framework for the study of state socialization. European Journal of International Relations 12: 89-118.

Friedrichs, Jörg. (2004) European Approaches to International Relations Theory: A House with Many Mansions. London: Routledge.

Friedrichs, Jörg, and Ole Wæver. (2009) Western Europe. In Arlene Tickner and Ole Wæver (eds) International Relations Scholarship Around the World. London and New York: Routledge.

Gang, Guo. (2006) Government Leadership Change and International Negotiations. The Chinese Journal of International Politics 1: 139-162.

Ganghua, Xiang, and Wang Yongxian. (2007) Preferences, Information and the Deterrence Game. The Chinese Journal of International Politics 1: 309-345.

De Goede, Marieke. (2008) The politics of preemption and the war on terror in Europe. European Journal of International Relations 14: 161-185.

Goldmann, Kjell. (1995) Im Westen Nichts Neues: Seven International Relations Journals in 1972 and 1992. European Journal of International Relations 1: 245-258.

Groom, A.J.R., and Peter Mandaville. (2001) Hegemony and Autonomy in International Relations: The Continental Experience. In Robert Crawford and Darryl Jarvis (eds) International Relations: Still an American Social Science?. Albany: SUNY Press.

Haixia, Qi. (2007) A Comparison of the Effectiveness of International Conflict Mediation Strategies. The Chinese Journal of International Politics 1: 589-622.

Hall, Todd. (2010) An Unclear Attraction: A Critical Examination of Soft Power as an Analytical Category. Chinese Journal of International Politics 3: 189-211.

Haraway, Donna. (1988) Situated Knowledges: The Science Question in Feminism and the Privilege of Partial Perspective. Feminist Studies 14: 575. 
He, Kai. (2011) A Realist's Ideal Pursuit. The Chinese Journal of International Politics.

Hoffmann, Stanley. (1977) An American Social Science: International Relations. Daedalus 106: 41-60.

Holsti, Kalevi. (1985) The Dividing Discipline: Hegemony and Diversity in International Theory. Boston: Allen \& Unwin.

Huang, Ping. (2010) The Status of the Social Sciences in China. In World Social Science Report: Knowledge Divides, Paris: UNESCO Publishing and International Social Science Council.

Huang, Xiaoming. (2007) The Invisible Hand: Modern Studies of International Relations in Japan, China, and Korea. Journal of International Relations and Development 10: 168-203.

Huiyun, Feng. (2009) Is China a Revisionist Power? Chinese Journal of International Politics 2: 313-334.

Hunter, Alan. (2009) Soft Power: China on the Global Stage. Chinese Journal of International Politics 2: 373-398.

Ish-Shalom, Piki. (2006) Theory as a hermeneutical mechanism: The democratic-peace thesis and the politics of democratization. European Journal of International Relations 12: 565-598.

Jørgensen, Knud. (2000) Continental IR Theory: The Best Kept Secret. European Journal of International Relations 6: 9-42.

Jørgensen, Knud, and Tonny Knudsen. (2006a) International Relations in Europe: Traditions, Perspectives and Destinations. Abingdon and New York: Routledge.

Jørgensen, Knud, and Tonny Knudsen. (2006b) The United Kingdom. In Knud Jørgensen and Tonny Knudsen (eds) International Relations in Europe: Traditions, Perspectives and Destinations. Abingdon and New York: Routledge.

Krebs, Ronald, and Patrick Thaddeus Jackson. (2007) Twisting tongues and twisting arms: The power of political rhetoric. European Journal of International Relations 13: 35-66.

Krippendorff, Ekkehart. (1987) The Dominance of American Approaches in International Relations. Millennium: journal of international studies 16: 207-214.

Leydesdorff, Loet, and Olle Persson. (2010) Mapping the Geography of Science: Distribution Patterns and Networks of Relations Among Cities and Institutes. Journal of the American Society for Information Science and Technology 61: 1622-1634.

Li, Bin. (2009) Insights into the Mozi and Their Implications for the Study of Contemporary International Relations. Chinese Journal of International Politics 2: 421-454.

Liang, Shoude. (1997) Constructing an International Relations Theory with Chinese Characteristics. Political Science 49: 23-39. 
Lipson, Michael. (2007) Peacekeeping: Organized Hypocrisy? European Journal of International Relations 13: 5-34.

Liu, Nian Cai, and Li Liu. (2005) University Rankings in China. Higher Education in Europe 30: $217-227$.

Lucarelli, Sonia, and Roberto Menotti. (2006) Italy. In Knud Jørgensen and Tonny Knudsen (eds) International Relations in Europe: Traditions, Perspectives and Destinations. Abingdon and New York: Routledge.

Maliniak, Daniel, Susan Peterson, and Michael Tierney. (2012) TRIP Around the World: Teaching, Research, and Policy Views of International Relations Faculty in 20 Countries. The College of William and Mary, Williamsburg, Virginia.

Mcdonald, Matt. (2008) Securitization and the Construction of Security. European Journal of International Relations 14: 563-587.

Mearsheimer, John. (2010) The Gathering Storm: China's Challenge to US Power in Asia. Chinese Journal of International Politics 3: 381-396.

Mingjiang, Li. (2008) China Debates Soft Power. Chinese Journal of International Politics 2: 287308.

Mitzen, Jennifer. (2006) Ontological Security in World Politics: State Identity and the Security Dilemma. European Journal of International Relations 12: 341-370.

Nianshen, Song. (2012) "Tributary" from a Multilateral and Multilayered Perspective. Chinese Journal of International Politics 5: 155-182.

Paltiel, Jeremy. (2010) Mencius and World Order Theories. Chinese Journal of International Politics 3: 37-54.

Paltiel, Jeremy. (2011) Constructing Global Order with Chinese Characteristics. The Chinese Journal of International Politics 4: 375-403.

Qin, Yaqing. (2009) Development of International Relations Theory in China. International Studies 46: 185-201.

Qin, Yaqing. (2011) Development of International Relations Theory in China: Progress Through Debates. International Relations of the Asia-Pacific 11: 231-257.

Qin, Yaqing. (2010) International Society as a Process: Institutions, Identities, and China's Peaceful Rise. Chinese Journal of International Politics 3: 129-153.

Qin, Yaqing. (2007) Why Is There No Chinese International Relations Theory? International Relations of the Asia-Pacific 7: 313-340.

Ren, Xiao. (2008) Toward a Chinese School of International Relations. In Gungwu Wang and Yongnian Zheng (eds) China and the New International Order. London and New York: Routledge. 
Ross, Andrew. (2006) Coming in from the cold: Constructivism and emotions. European Journal of International Relations 12: 197-222.

Segura, Caterina. (2006) Spain. In Knud Jørgensen and Tonny Knudsen (eds) International Relations in Europe: Traditions, Perspectives and Destinations. Abingdon and New York: Routledge.

Snyder, Jack. (2008) Some Good and Bad Reasons for a Distinctively Chinese Approach to International Relations Theory. Working Paper prepared for the Annual Meeting of the American Political Science Association, August 28-31, 2008.

Song, Xinning. (2001) Building International Relations Theory with Chinese Characteristics. Journal of Contemporary China 10: 61-74.

Stritzel, Holger. (2007) Towards a theory of securitization: Copenhagen and beyond. European Journal of International Relations 13: 357-383.

Tammen, Ronald, and Jacek Kugler. (2006) Power Transition and China-US Conflicts. Chinese Journal of International Politics 1: 35-55.

Tickner, Arlene. (2003) Seeing IR Differently: Notes from the Third World. Millennium: Journal of International Studies 32: 295-324.

Tickner, Arlene, and Ole Wæver. (2009) International Relations Scholarship Around the World. London: Routledge.

Vuori, Juha. (2008) Illocutionary logic and strands of securitization: Applying the theory of securitization to the study of non-democratic political orders. European Journal of International Relations 14: 65-99.

Walt, Stephen. (2011) Is IR Still “an American Social Science?" Available at: http://walt.foreignpolicy.com/posts/2011/06/06/is_ir_still_an_american_social_science. (Accessed October 25, 2012).

Wang, Jisi. (2002) International Relations Studies in China Today: Achievements, Trends, and Conditions. A Report to the Ford Foundation. Ford Foundation: 1-25.

Wang, Yiwei. (2007) Between Science and Art: Questionable International Relations Theories. Japanese Journal of Political Science 8: 191-208.

Wang, Yiwei. (2009) China: Between Copying and Constructing. In Arlene Tickner and Ole Wæver (eds) International Relations Scholarship Around the World. London and New York: Routledge.

Wei, Lili. (2010) Funding and Assessment of Humanities and Social Science Research in China. In World Social Science Report: Knowledge Divides, Paris: UNESCO.

Womack, Brantly. (2012) Asymmetry and China's Tributary System. Chinese Journal of International Politics 5: 37-54. 
Wæver, Ole. (2004) Aberystwyth, Paris, Copenhagen New "Schools" in Security Theory and Their Origins Between Core and Periphery. Paper presented at the annual meeting of the International Studies Association, Montreal, March 17-20, 2004: 1-22.

Wæver, Ole. (1998) The Sociology of a Not So International Discipline: American and European Developments in International Relations. International Organization 52: 687-727.

Xiaomin, Zhang, and Xu Chunfeng. (2007) The Late Qing Dynasty Diplomatic Transformation: Analysis from an Ideational Perspective. Chinese Journal of International Politics 1: 405445.

Yan, Fengqiao. (2010) The Academic Profession in China in the Context of Social Transition: An Institutionalist Perspective. European Review 18: 99-116.

Yan, Xuetong. (2011) Ancient Chinese Thought, Modern Chinese Power. Princeton: Princeton University Press.

Yan, Xuetong. (2006) The Rise of China and its Power Status. Chinese Journal of International Politics 1: 5-33.

Yan, Xuetong. (2008) Xun Zi's Thoughts on International Politics and Their Implications. Chinese Journal of International Politics 2: 135-165.

Yongjin, Zhang, and Barry Buzan. (2012) The Tributary System as International Society in Theory and Practice. Chinese Journal of International Politics 5: 3-36.

Yongping, Feng. (2006) The Peaceful Transition of Power from the UK to the US. Chinese Journal of International Politics 1: 83-108.

Yuan-kang, Wang. (2012) Managing Regional Hegemony in Historical Asia: The Case of Early Ming China. Chinese Journal of International Politics 5: 129-153.

Zhang, Feng. (2009) Rethinking the "Tribute System": Broadening the Conceptual Horizon of Historical East Asian Politics. Chinese Journal of International Politics 2: 545-574.

Zhang, Feng. (2011) The Tsinghua Approach and the Inception of Chinese Theories of International Relations. The Chinese Journal of International Politics.

Zhang, Xiaoming, and Barry Buzan. (2010) Correspondence: Debating China's Peaceful Rise. The Chinese Journal of International Politics 3: 447-460.

Zhang, Yongjin. (2002) Review: International Relations Theory in China Today: The State of the Field. The China Journal 47: 101-108.

Zhang, Yongjin. (2003) The "English School" in China: a Travelogue of Ideas and Their Diffusion. European Journal of International Relations 9: 87-114.

Zhongbo, Zhu, and Wang Ning. (2008) Discourses on Salt and Iron and China's Ancient Strategic Culture. Chinese Journal of International Politics 2: 263-286. 
Zhou, Fangyin. (2011) Equilibrium Analysis of the Tributary System. The Chinese Journal of International Politics 4: 147-178.

Zhou, Fangyin. (2007) The Role of Ideational and Material Factors in the Qing Dynasty Diplomatic Transformation. Chinese Journal of International Politics 1: 447-474.

Zhou, Fangyin. (2010) Wars of Attrition and the Timing of Peace Settlements. The Chinese Journal of International Politics 3: 79-123.

Zhou, Ping, Xinning Su, and Loet Leydesdorff. (2010) A Comparative Study on Communication Structures of Chinese Journals in the Social Sciences. Journal of the American Society for Information Science and Technology 61: 1360-1376.

\footnotetext{
${ }^{\mathrm{i}}$ The survey data was gathered in the summer of 2010. The survey was distributed to 305 Chinese IR scholars at top universities and 148 scholars responded (49\%) although some of the more demanding questions have a lower response rate.

ii There are fewer articles in CJIP in this period in part because it published fewer articles per issue and because it did not transition from biannual to quarterly issues until 2010.
} 